\title{
Juvenile Justice
}

\author{
Ton Liefaard
}

The Oxford Handbook of Children's Rights Law

Edited by Jonathan Todres and Shani M. King

Print Publication Date: Apr 2020 Subject: Law, Human Rights and Immigration

Online Publication Date: May 2020 DOI: 10.1093/oxfordhb/9780190097608.013.15

\section{Abstract and Keywords}

Juvenile justice is a children's rights issue. This chapter sheds light on the international children's rights framework for juvenile justice and elaborates on its implications for juvenile justice systems at the domestic level. It discusses the comprehensive nature of the international legal framework and addresses key implementation challenges in light of the complexity of and controversies inherently related to juvenile justice. In doing so, the chapter shows there are specific challenges that ought to be recognized in order to enhance the protection of children in conflict with the law and secure a fair and child-specific approach. At the same time, it points at the progress made since adoption of the UN Convention on the Rights of the Child (CRC), which justifies the conclusion that the future of children's rights implementation in the context of juvenile justice is a hopeful one.

Keywords: children's rights, juvenile justice, children in conflict with the law, Convention on the Rights of the Child, fair trial, due process, child-friendly justice, pedagogical orientation, reintegration.

\section{Introduction}

INTERNATIONAL instruments and jurisprudence regulating children's rights in the context of juvenile justice recognize that state intervention-and consequently limitations of human rights and fundamental freedoms of an individual child-can be justified when that child is in conflict with the law. ${ }^{1}$ The justification lies in the protection of the interests of others and/or society as a whole, which encompasses the rehabilitation and reintegration of the child and which gives juvenile justice a fundamentally different orientation than adult criminal justice. International children's rights, as laid down in the almost universally ratified UN Convention on the Rights of the Child (CRC), ${ }^{2}$ aim to protect the rights and interests of the individual child by stipulating that states parties are under the obligation to

recognize the right of every child alleged as, accused of, or recognized as having infringed the penal law to be treated in a manner consistent with the promotion of the child's sense of dignity and worth, which reinforces the child's respect for the 


\section{Juvenile Justice}

human rights and fundamental freedoms of others and which takes into account the child's age and the desirability of promoting the child's reintegration and the child's assuming a constructive role in society. (Article 40(1))

This international children's rights approach has resulted in an extensive and comprehensive legal framework, developed at the international and regional level, consisting of specific rules with regard to the treatment of children in conflict with the law. These rules revolve around each individual child's entitlement to be treated fairly and with respect for his ${ }^{3}$ inherent dignity and in a child-specific manner. This essentially calls for a criminal justice system specifically designed for and tailored to the needs and deeds of children (Article 40(3)) and finds support in a growing body of scientific research on child development, including brain development. ${ }^{4}$ In a landmark case, Roper v. (p. 280) Simmons, ${ }^{5}$ in which the death penalty was ruled unconstitutional as applied to minors, the US Supreme Court held that children are less culpable than adults due to their "susceptibility to immature and irresponsible behavior." The Court in Roper observed that "it would be misguided to equate the failings of a minor with those of an adult, for a greater possibility exists that a minor's character deficiencies will be reformed." 6

Specific attention for children in conflict with the law predates the CRC, to earlier recognition in domestic juvenile criminal justice systems, which began to emerge at the beginning of the twentieth century, mostly in Western Europe and the United States. ${ }^{7}$ This also explains why the first international instrument on children's rights, the Declaration of Geneva, adopted by the League of Nations in 1924, explicitly refers to the delinquent child as a child that "must be reclaimed." 8

This chapter sheds light on the international children's rights framework for juvenile justice and elaborates on its implications for juvenile justice systems at the domestic level. Without disregarding the importance of prevention of juvenile delinquency and the interaction between the juvenile justice system and other systems that are relevant for children and their families, such as the welfare system, the child protection system, or the (mental) health care system, this chapter focuses on the juvenile justice system only. It begins, like international children's rights standards do, by recognizing that-across the globe-children are involved in criminal justice systems, and that is likely to remain the case. After elaborating on the international legal framework and its key instruments, and the development of the international agenda with regard to juvenile justice, the chapter addresses some of the main implications of international children's rights for domestic juvenile justice systems, more specifically the establishment of a child-specific criminal justice system and the safeguarding of fair treatment, including the right to participate effectively in justice proceedings. The chapter subsequently addresses some of the key challenges with regard to the implementation of children's rights at the domestic level, in light of the particular complexity of and controversies related to juvenile justice. The chapter concludes by suggesting that despite the many challenges, much has been achieved, which makes the future of children's rights implementation in the context of juvenile justice a hopeful one. 


\section{International Children's Rights and Juvenile Justice at the International Level}

\subsection{Standard-Setting at the International Level}

The CRC forms the core of a comprehensive international legal framework that has particular meaning for juvenile justice. Article 40 of the CRC builds on and essentially codifies the 1985 UN Standard Minimum Rules for the Administration of Juvenile (p. 281) Justice (Beijing Rules), ${ }^{9}$ which were the first relevant set of juvenile justice standards developed at the international level and provide rules regarding a wide variety of aspects of juvenile justice, including the minimum age of criminal responsibility, investigation and prosecution, adjudication and disposition, and (non-)institutional treatment. The CRC provision proclaims the establishment of a specific justice system for children and sets the objectives of juvenile justice (paras. 3 and 1, respectively). It also provides that children in conflict with the law are entitled to be treated fairly by granting them fair trial rights (para. 2.). In addition to CRC Article 40, CRC Article 37(b) prohibits torture and other forms of cruel, inhuman, or degrading treatment or punishment (para. a) and compels states parties to use deprivation of liberty only as a last resort and for the shortest appropriate period of time. CRC Article 37(c) and (d) regulate the treatment of children deprived of liberty and provide procedural safeguards. Together with the CRC's general principles, ${ }^{10} \mathrm{CRC}$ Articles 40 and 37 have served as a catalyst for further standard setting at the international and regional level.

At the international level, two additional instruments were adopted by the UN General Assembly in 1990: the UN Rules for the Protection of Juveniles Deprived of their Liberty (also known as the Havana Rules) ${ }^{11}$ and the UN Guidelines for the Prevention of Juvenile Delinquency (the Riyadh Guidelines). ${ }^{12}$ The Havana Rules "are intended to establish minimum standards ... for the protection of juveniles deprived of their liberty in all forms, consistent with human rights and fundamental freedoms, and with a view to counteracting the detrimental effects of all types of detention and to fostering integration in society."13 To this end, they provide detailed rules, including rules on admission, conditions, contact with the outside world, disciplinary measures, inspection and complaint procedures, and reintegration. The Riyadh Guidelines aim to guide UN member states on how to set up a successful strategy on the prevention of juvenile delinquency that is grounded in human rights and child-centered, that is: a strategy that "[y]oung persons should have an active role and partnership within society and should not be considered as mere objects of socialization and control."14 Like the Beijing Rules, the Havana Rules and the Riyadh Guidelines are not legally binding. However, the CRC Committee has been consistent in its call upon states parties to integrate these international standards in a "national and comprehensive national juvenile justice policy." 15 It has also used the Beijing Rules and the Havana Rules for the interpretation of the obligations of states parties under the $\mathrm{CRC}^{16}$ and calls upon states to "fully implement" the Havana Rules. ${ }^{17}$ This finds support in the way regional human rights courts and domestic courts include such sources of soft international law, as the Beijing Rules and the Havana Rules in their case law as a basis of inter- 


\section{Juvenile Justice}

pretation. ${ }^{18}$ Consequently, it can be argued that both the CRC and the UN resolutions ought to be seen as components of a comprehensive children's rights framework regulating juvenile justice.

General human rights instruments that are particularly relevant for criminal justice and target children like all other human beings complement the children's rights framework. ${ }^{19}$ This is particularly true for the provisions of the 1966 International Covenant on Civil and Political Rights (ICCPR) ${ }^{20}$ on fair trial (Articles 14 and 15), on treatment and punishment of individuals (Articles 6 and 7), and on deprivation of liberty (Articles 9 (p. 282) and 10) that have informed the drafters of the CRC and formed the basis for CRC Articles 40 and 37. ${ }^{21}$ In addition, ICCPR Article 24 recognizes that a child is entitled to a higher level of protection "as ... required by his status as a minor, on the part of the family, society and the State," a notion that underlies the CRC as well and justifies a child-specific focus in the context of juvenile justice. Other general instruments, such as the 1985 Convention against Torture (CAT), ${ }^{22}$ the 1965 International Convention on the Elimination of All Forms of Racial Discrimination, ${ }^{23}$ the 2015 UN Standard Minimum Rules for the Treatment of Prisoners (the Nelson Mandela Rules), ${ }^{24}$ and the 1990 UN Standard Minimum Rules for Non-custodial Measures (the Tokyo Rules) ${ }^{25}$ also are relevant for children in conflict with the law.

\subsection{Standard-Setting at the Regional Level}

In different regions, various specific instruments and case law add to the international legal framework relevant for juvenile justice. The European and the Inter-American regions report the most prominent developments in this regard. Again, such general human rights instruments as the American Convention on Human Rights (ACHR) and the European Convention on Human Rights bear relevance for children and occasionally refer to children. ${ }^{26}$ The Inter-American Court of Human Rights and the Inter-American Commission on Human Rights (Inter-American Commission) have developed a growing body of judgments and decisions, respectively, with specific relevance for juvenile justice, including cases involving the deprivation of liberty and arrest and the detention and ill treatment of children by the police. ${ }^{27}$ An important example is the landmark case Villangrán Morales v. Guatemala (also known as the "Street Children" case), in which the Court held that the state had inadequately protected the "street children" against "a systematic practice of aggression ... carried out by members of the State security forces, which included threats, persecution, torture, forced disappearance and homicide." ${ }^{28}$ In having applied or tolerated "the prevailing pattern of violence against 'street children' in Guatemala," which "culminated in the death of the minors," 29 the state had disregarded its obligations under ACHR Article 19, which grants "[e]very minor child the right to measures of protection as required by his condition as a minor on the part of his family, society, and the state." The Court found that "[b]oth the [ACHR] and the [CRC] form part of a very comprehensive international corpus juris for the protection of the child that should help ... establish the content and scope of [Article 19 of the ACHR]." 30 It emphasized the need to safeguard "non-discrimination, special assistance for children deprived of their family environment, the guarantee of survival and development of the child, the right to 


\section{Juvenile Justice}

an adequate standard of living, and the social rehabilitation of all children who are abandoned or exploited." 31 As Monica Feria-Tinta observes, "[i]n the CRC, the Inter-American System has found an important tool that has contributed to better state the law in the Americas," 32 which points at the Court's leading role in integrating international and regional children's rights standards; a role in which the Court was joined later by the InterAmerican Commission, which additionally (p. 283) considered the views of the CRC Committee expressed in its General Comments and Concluding Observations as relevant reference material for interpretation purposes. ${ }^{33}$

At the European level, the Committee of Ministers of the Council of Europe has issued recommendations and guidelines that are relevant for the juvenile justice systems of the forty-seven member states. The most important ones are the 2003 Recommendation concerning new ways of dealing with juvenile delinquency and the role of juvenile justice, ${ }^{34}$ the 2008 European Rules for juvenile offenders subject to sanctions or measures ${ }^{35}$ (European Rules for Juvenile Offenders), and the 2010 Guidelines on child-friendly justice (the Guidelines). ${ }^{36}$ While the 2003 Recommendation provides recommendations on how to respond to juvenile delinquency in light of contemporary juvenile justice and scientific insights, the European Rules for juvenile offenders set specific rules for the protection of the rights and interests of juvenile offenders subjected to custodial and non-custodial interventions. The Guidelines provide guidance to Council of Europe member states on how to enable children to participate effectively in justice proceedings, including juvenile justice proceedings. The Guidelines have emerged from the case law of the European Court of Human Rights (European Court) and the CRC Committee's General Comment No. 10, in which a child's right to effective participation has been recognized as part of the right to a fair trial. ${ }^{37}$ Since their adoption, the Guidelines have informed the European Court's case law in matters related to justice proceedings, including juvenile justice, ${ }^{38}$ and legislation developed by the European Union, specifically on the protection of children in conflict with the law. ${ }^{39}$ The Guidelines serve as an example for similar standard-setting initiatives in other parts of the world and by certain professional organizations. ${ }^{40}$ In addition to case law on effective participation, the European Court has developed juvenile justice case law, specifically on the right to legal assistance during police interrogations, ${ }^{41}$ the use of pre-trial detention, ${ }^{42}$ and on the conditions of detention. ${ }^{43}$ The Court has, thus, incorporated international children's rights standards, including soft law instruments, in its jurisprudence under the European Convention on Human Rights. ${ }^{44}$ In addition, it has drawn upon the reports and standards of the European Committee on the Prevention of Torture, which target the protection of children deprived of their liberty across the Council of Europe. ${ }^{45}$

\subsection{A Comprehensive International Legal Framework and the Emerg- ing Global Interest in Juvenile Justice}

These regional developments show that the different standard-setting initiatives at the international and regional level are interconnected. As a result, the world has witnessed the emergence of a comprehensive international legal framework of human and children's rights standards relevant to juvenile justice. At the same time, it is fair to say that, so far, 


\section{Juvenile Justice}

not all parts of the world have been reached. Thus, there remain questions as to what extent this international legal framework on juvenile justice represents a universal (p. 284) movement and the extent to which there is support at the national level in all countries, notwithstanding the CRC Committee's admonition that a juvenile justice system that is compliant with the CRC and related international standards "will provide States parties with possibilities to respond to children in conflict with the law in an effective manner serving not only the best interests of children, but also of the short- and long-term interests of the society at large." 46

The development of the international children's rights framework relevant for juvenile justice, which started with the adoption of the 1985 Beijing Rules and the CRC, forms part of an emerging and global interest in this particular field that has manifested itself at the international, regional, and domestic level. It has paved the way for law reform in many domestic jurisdictions ${ }^{47}$ and for a growing body of jurisprudence, internationally and domestically. ${ }^{48}$ In addition, it has raised significant awareness around the importance of children's rights protection in this particular field and has contributed to our understanding of the implementation of children's rights and related challenges. Over the years, numerous reports have been produced by intergovernmental agencies, bodies, and representatives ${ }^{49}$ as well as civil society organizations and coalitions. ${ }^{50}$ These reports not only show the gaps and challenges with regard to implementation; they also provide guidance and support on how to safeguard the generally vulnerable position of children in conflict with the law.

\section{Implications of International Children's Rights for Juvenile Justice}

International children's rights have many implications for juvenile justice systems at the domestic level. ${ }^{51}$ There are two assumptions underlying CRC Article 40. ${ }^{52}$ First, children in conflict with the law are entitled to be treated in a child-specific manner. Second, each child is entitled to be treated fairly and with respect for his inherent dignity. This section elaborates on these "limbs" of the CRC framework and addresses some of their main implications.

\subsection{A Specific Justice System for Children}

The call for a specific justice system for children can be found in CRC Article 40(3), which provides that "States Parties shall seek to promote the establishment of laws, procedures, authorities and institutions specifically applicable to children alleged as, accused of, or recognized as having infringed the penal law." The CRC itself does not provide much further guidance on this call for specificity, unlike, for example, ACHR Article 5(5), which proclaims the establishment of "specialized tribunals" for minors. (p. 285) Article 40 does, however, require the establishment of a minimum age of criminal responsibility and "measures dealing with [children in conflict with the law] without resorting to judicial proceedings," which refers to "diversion" (see the following section). More guidance can be found 


\section{Juvenile Justice}

in the Beijing Rules, CRC Committee General Comment No. 10, and CRC Article 40(1), which elaborate on the specific objectives of juvenile justice (section 3.1.1) and underscore the significance of specialization (section 3.1.2).

\subsubsection{The Objectives of the Juvenile Justice System-Pedagogical Orientation}

According to CRC Article 40(1), children subjected to criminal justice proceedings must be treated in a manner that takes into account the age of the child and that focuses on the child's reintegration in society. According to the CRC Committee, this means that the juvenile justice system ought to recognize that "children differ from adults in their physical and psychological development, and their emotional and educational needs," which "constitute the basis for the lesser culpability of children in conflict with the law." 53 It also means that children should be treated differently from adults and that state intervention should give primary consideration to the individual interests of the child offender and his future role in society. This call for a specific approach for children reflects a pedagogical or educational orientation, which makes the juvenile justice system fundamentally different from the adult criminal justice system.

CRC Article 40(1) also refers to the "the promotion of child's sense of dignity and worth, which reinforces the child's respect for the human rights and fundamental freedoms of others." This provision should be understood in light of the aims of education as laid down in CRC Article 29 and shows that prevention (i.e., the prevention of recidivism) is a key focus point of juvenile justice. ${ }^{54}$ That is not to say that the juvenile justice system should not recognize the more general objectives of criminal justice, including retribution, deterrence, protection of society, and the restoration and reparation for victims and communities (see also CRC Article 39). The CRC Committee underscores, however, that "the protection of the best interests of the child means, for instance, that the traditional objectives of criminal justice, such as retribution, must give way to rehabilitation and restorative justice objectives in dealing with child offenders," which "can be done in concert with attention to effective public safety." 55

The pedagogical orientation and strong focus on education and reintegration also imply that the potential negative impact of a justice intervention on the child's short- and longterm interests should be acknowledged, which essentially comes down to a call for the use of juvenile justice interventions as an ultimum remedium. This is directly linked with the prevention of juvenile delinquency, ${ }^{56}$ the prevention of discrimination in the context of juvenile justice, ${ }^{57}$ the exclusion of status offenses from prosecution, ${ }^{58}$ and the setting of a minimum age of criminal responsibility (MACR). According to CRC Article 40(3)(a), "State Parties shall seek to promote ... establishment of a minimum age below which children shall be presumed not to have the capacity to infringe the penal law." As Jaap Doek observes, the MACR is about the age at which a child can be prosecuted and held criminally accountable for committing an offense. ${ }^{59}$ The main (p. 286) purpose of the MACR is to recognize that there is a certain group of children who should not be prosecuted because of the irrefutable presumption that they are not mature enough to be held criminally accountable. At the same time, it is important to recognize that children underneath the 


\section{Juvenile Justice}

MACR may be involved in criminal offences, which raises the question of how to respond to these children in an effective, rights-based manner. ${ }^{60}$

The call for states parties to use diversion "[w]henever appropriate and desirable"61_instead of resorting to formal judicial proceedings-should also be understood as part of the pedagogical orientation of a child-specific criminal justice system. Diversion serves multiple objectives, including avoiding the exposure of children to the negative impact of formal judicial proceedings, such as stigmatization, which could jeopardize reintegration. In addition, diversion serves the objective of effectuating a quick response to criminal behavior, since it aims to keep the child from going through lengthy court proceedings, which is considered important for the effectiveness of justice interventions. ${ }^{62}$ The CRC provides states with the discretion to decide "on the exact nature and content of the measures" when using diversion. ${ }^{63}$ The CRC Committee elaborates further in its General Comment No. 10 on the meaning of diversion and the importance of sharing good practices and highlights the importance of a full respect for the human rights of the child and legal safeguards. ${ }^{64}$ Among others, this means that diversion should be used only when there is "compelling evidence" and that the child "freely and voluntarily admits responsibility." 65 The CRC Committee notes that "it is clear that a variety of community based programmes have been developed, such as community service, supervision and guidance by, for example, social workers or probation officers, family conferencing and other forms of restorative justice including restitution to and compensation of victims."66

CRC Article 40(1)'s reference to the age of the child also underscores the need for a child-specific focus, refers to differences between children in terms of their developmental stage, and can be seen as a directive to treat children in accordance with their age and maturity. ${ }^{67}$ This has implications for their individual accountability (and therefore links to the MACR), the determination of the appropriate intervention, and the effective participation of children, including by ensuring their right to information, for example, on charges and dispositions. The age of the child also plays a role in relation to other critical issues for children, such as the involvement of parents or legal guardians ${ }^{68}$ and the deprivation their liberty. ${ }^{69}$

\subsubsection{Specificity and Specialization}

One may wonder whether the call for a specific juvenile justice system presupposes that a state should separate its justice system for children entirely from the adult system. CRC Article 40(3), as well as CRC Committee's interpretation, suggests that specificity and specialization matters more than strict separation. ${ }^{70}$ The safeguarding of specific treatment or punishment for children can be realized through the inclusion of child-specific elements in existing legislation, procedures, and policies and through specialization of the authorities and institutions involved. Therefore, it seems not necessary to draw up separate legislation for children, even though many countries have developed (p. 287) separate legislation regulating juvenile justice, which certainly contributes to greater child-specificity in the focus of the justice system. ${ }^{71}$ States will meet the requirements of CRC Article 40(3) if they include special juvenile justice provisions in existing substantive and procedural legislation regulating the criminal procedure and penal law, like many European 


\section{Juvenile Justice}

countries have done in various ways. ${ }^{72}$ In general, states' willingness, efforts, and need to adopt special juvenile justice acts depend on their already existing legal frameworks. ${ }^{73}$

In addition to legislation, specific implementation measures for children are required to make the existing justice infrastructure and its actors more sensitive to children and to children's rights. According to the CRC Committee, states parties should "develop and implement a comprehensive juvenile justice policy." 74 This policy should also embrace the proclaimed general principles of the CRC, Articles 2, 3, 6 and 12,75 and encompass other relevant provisions, such as CRC Article 39, on the recovery and reintegration of victims. Specialization of authorities and institutions, including police, law enforcement, judicial authorities, lawyers, probation services, and institutions, should be part of this policy as well. ${ }^{76}$

Although the international legal framework does not seem to force states to separate children in conflict with the law entirely from adults, a stricter approach may be required concerning the use of deprivation of liberty. Article 37(c) of the CRC provides that children should be separated from adults if they are deprived of their liberty. This provision builds on ICCPR Article 10, ${ }^{77}$ which calls for strict separation or segregation of children in pre-trial detention or imprisoned from adults. The rationale behind this requirement is that children must be protected against the negative influence of adult detainees or prisoners, including violence and abuse and criminal contamination. ${ }^{78} \mathrm{In}$ fact, the best interests of the child standard, which should be the paramount consideration in this situation, requires separation, thereby ruling out administrative justifications for mixing children and adults. ${ }^{79}$

The separation requirement should, however, also be understood in light of the objectives of juvenile justice, which assumes a child-specific approach with a clear pedagogical orientation. In other words, it is not enough to build a separate institution for children. Such institutions should be regulated and equipped in such a way that they safeguard a specific and specialized approach for children, including education and reintegration programs, which may, if appropriate, also include mental health treatment or drug rehabilitation. In the context of deprivation of liberty, it has been argued that education, specific treatment if appropriate, and reintegration programs are essential elements of the child's legal status under Article 37(c) of the CRC. In other words, children who are deprived of liberty are entitled to be supported in their reintegration, an obligation of the state that is inherent to the decision to deprive a child of his liberty, regardless of the justification for it. ${ }^{80}$

It can be concluded that specificity and specialization are key in light of the objectives of juvenile justice. Moreover, an over emphasis on separation runs the risk of disregarding that children have the same entitlements as adults revolving around the requirement of fair treatment. Treating children in conflict with the law with fairness and with respect (p. 288) for their inherent dignity can be considered fundamental in light of the need for the system to reinforce the child's respect for the human rights and fundamental freedoms of others and the role that this plays in their reintegration. ${ }^{81}$ Understandably, the CRC Committee raises the question: "If the key actors in juvenile justice, such as police 


\section{Juvenile Justice}

officers, prosecutors, judges and probation officers, do not fully respect and protect [the child's right to be treated fairly], how can they expect that with such poor examples the child will respect the human rights and fundamental freedom of others?" 82 The right of the child to a fair trial starts with the assumption that children have the same fair trial rights but that-also in this regard-child specificity matters, both in terms of specific entitlements and specific implementation.

\subsection{Fair Trial-Child-Friendly Justice}

\subsubsection{Children's Right to a Fair Trial-Equal and Specific Rights}

The starting point of human rights law is that there should be no distinction between adults and children as far as the right to a fair trial (or due process) is concerned. "All persons shall be equal before the courts and tribunals," according to ICCPR Article 14(1), which served as the foundation of Article 40(2) of the CRC, together with ICCPR Article 15, embodying the principle of legality, including the prohibition of retroactive justice and sentencing. ${ }^{83}$ Consequently, Article 40 of the CRC repeats fundamental fair trial rights, in particular: the presumption of innocence, ${ }^{84}$ the right not to incriminate oneself, ${ }^{85}$ the right to prompt information on the charges in a language one understands, ${ }^{86}$ the right to be tried before a competent, independent, and impartial authority or judicial body, ${ }^{87}$ the right to cross-examine witnesses, ${ }^{88}$ and the right to free assistance of an interpreter. ${ }^{89}$

Specifically for children, CRC Article 40(2) lists additional fair trial rights or formulates certain rights in such a way that they have more specific meaning for children. First, a child alleged as or accused of having infringed the penal law is entitled to have the criminal trial determined "without delay by a competent, independent and impartial authority or judicial body." 90 The use of the wording "without delay"-rather than "without undue delay" or "within reasonable time"91_assumes that children are entitled to a trial that is speedier. ${ }^{92}$ According to the CRC Committee, this assumption is based on the "[international] consensus that for children in conflict with the law the time between the commission of the offence and the final response to this act should be as short as possible."93 Another child-specific element of CRC Article 40(2) is the right of the child to have his privacy "fully respected at all stages of the proceedings." 94 According to the CRC Committee, this implies that trial in juvenile court should "as a rule" 95 be held behind closed doors-in camera. The child's right to privacy also relates to criminal records. The CRC Committee recommends that states develop legislation which provides that the criminal records of a child be erased once he reaches the age of eighteen and should not thereafter be used against the same offender in adult proceedings. ${ }^{96}$

(p. 289) Furthermore, CRC Article 40(2) explicitly refers to the child's parents or legal guardians, who can be present during hearings to provide general psychological and emotional assistance to the child. Parents can also play a role in relation to information on the charges, which the child should receive "as soon as possible" 97 and in a childfriendly manner. ${ }^{98}$ The reference to parents (or legal guardians) fits in the more general recognition in the CRC of the child-parent/family relationship, also in light of the child's evolving capacities. ${ }^{99} \mathrm{CRC}$ Article 37(c) provides that the child who is deprived of liberty 


\section{Juvenile Justice}

has the right to maintain contact with his family, unless this is not regarded as being in the best interests of the child. Article 40(2) of the CRC contains the same best interests clause, which underscores the importance of recognizing that parental involvement is not always in the child's interests and can therefore be limited or even excluded. ${ }^{100}$

Finally, it is important to mention the child's right to legal or other appropriate assistance. ${ }^{101}$ The European Court of Human Rights has recognized that, as part of the right to a fair trial, an arrested child has the right to legal counsel during the initial police interrogations, including the right to have a lawyer present during these interrogations free of charge. ${ }^{102}$ The CRC Committee has taken the position that legal or other appropriate assistance should be free of charge and recommends that "adequate legal assistance" be provided "as much as possible." 103 There is a potential tension between the legal protection offered to children, particularly in the earliest stages of the criminal justice process, and the importance of responding diligently and in a pedagogically effective manner. ${ }^{104} \mathrm{~A}$ lawyer may not be available, for practical reasons, which could result in police custody or detention until the lawyer arrives. In addition, lawyers may not be sufficiently specialized to understand that in the first stages there may be other options, including diversion, which may affect the defense strategy and, for example, the level of cooperation and the usage of the right to remain silent. ${ }^{105}$ This underscores the need for specialized lawyers. Non-legal assistance, for example by a social worker, also may support good outcomes, and it is important to note that the CRC leaves room for providing mere non-legal assistance. ${ }^{106}$ It can be assumed that the quality of the assistance matters the most. ${ }^{107}$ At the same time, the importance of legal assistance, particularly during the first stages, should not be underestimated. ${ }^{108}$ One may also wonder why children in conflict with the law do not have the mandatory right to legal assistance ${ }^{109}$ Children deprived of their liberty have the right to legal and other appropriate assistance. ${ }^{110}$

\subsubsection{Right to Effective Participation-Child-Friendly Justice}

The right of the child to effective participation as part of the right to a fair trial was first recognized by the European Court of Human Rights in the landmark case T. \& V. v. UK (Bulger case). ${ }^{111}$ In this case, the European Court observed, with explicit reference to CRC Article 40, that "it is essential that a child charged with an offence is dealt with in a manner which takes full account of his age, level of maturity and intellectual and emotional capacities, and that steps are taken to promote his ability to understand and participate in the proceedings." ${ }^{112}$ In this particular case, the Court ultimately concluded that the two young boys were unable to participate effectively, since it is was "highly unlikely" that they would have felt "sufficiently uninhibited, in the tense courtroom and (p. 290) under public scrutiny, to have consulted with [their lawyers] during the trial or, indeed, that, given [their] immaturity and [their] disturbed emotional state, [they] would have been capable outside the courtroom of cooperation with [their] lawyers and giving them information for the purposes of [their] defence." ${ }^{113}$ In S.C. $v$ U.K., the European Court ruled that “'effective participation' ... presupposes that the accused has a broad understanding of the nature of the trial process and of what is at stake for him or her, including the significance of any penalty which may be imposed" and that Article 6's right to a fair trial does 


\section{Juvenile Justice}

not require that a child on trial should "understand or be capable of understanding every point of law or evidential detail."114 This case law, in which the court essentially highlighted specific aspects of effective participation, was later embraced by the CRC Committee in its General Comment No. $10^{115}$ and paved the way for the development of the concept of "child-friendly justice." 116 According to the CRC Committee, the right to effective participation has implications for each stage of the juvenile justice process ${ }^{117}$ and revolves around Rule 14 of the Beijng Rules, which provides that proceedings "shall be conducted in an atmosphere of understanding, which shall allow the juvenile to participate therein and to express herself or himself freely." 118 The CRC Committee observes that the child "needs to comprehend the charges, and possible consequences and penalties, in order to direct the legal representative, to challenge witnesses, to provide an account of events, and to make appropriate decisions about evidence, testimony and the measure(s) to be imposed." In addition, it notes that "[t]aking into account the child's age and maturity may also require modified courtroom procedures and practices," that "a child cannot be heard effectively where the environment is intimidating, hostile, insensitive or inappropriate for her or his age," and that "[p]articular attention needs to be paid to the provision and delivery of child-friendly information, adequate support for self-advocacy, appropriately trained staff, design of court rooms, clothing of judges and lawyers." ${ }^{119}$ In other words, juvenile justice proceedings must be both "accessible and child-appropriate,"120 which according to the CRC Committee, also means that "[t]he court and other hearings of a child in conflict with the law should be conducted behind closed doors." 121 These CRC Committee recommendations find support in research on effective participation of children in youth court proceedings ${ }^{122}$ and also are supported by children themselves. ${ }^{123}$

The Guidelines on child-friendly justice adopted by the Council of Europe in 2010 build on the child's right to be heard and the recognition of the right to effective participation and provide specific guidance to member states on how to make justice systems more childfriendly. ${ }^{124}$ States should consider the position of the child before, during, and after justice proceedings and safeguard access to information; ensure the protection of private and family life as well as access to legal counsel and representation; avoid undue delay; and ensure the provision of an appropriate environment in and around judicial proceedings (including after disposition) and child-specific training for professionals. ${ }^{125}$

In conclusion, the international children's rights framework recognizes that children in conflict with the law have the right to be treated fairly, which includes the right to participate effectively in justice proceedings and comes with child-specific implications. (p. 291) As previously mentioned, there may be a tension between safeguarding the right to a fair trial and the pedagogical orientation of juvenile justice. A good understanding of the specific context in which the balancing exercise has to take place seems to be a prerequisite for an effective implementation of children's rights. Interdisciplinary research aiming to achieve a better understanding of the meaning of children's rights in the context of juvenile justice could assist in supporting states to live up to their obligations under international law. ${ }^{126}$ Attempts to develop regional standards, such as the Guidelines on childfriendly justice, assist states in this regard. It is also worth noting that the Guidelines were drafted with input from children and that there has been research on their imple- 
mentation, ${ }^{127}$ research which should be supported and be used to carefully evaluate the meaning of child-friendly justice for children in conflict with the law and juvenile justice professionals. ${ }^{128}$

\section{Implementation of Children's Rights: Reform and Persistent Challenges}

\subsection{Juvenile Justice Reform}

Over the past three decades, juvenile justice reform has taken place across the globe, and the influence of international children's rights on this reform cannot be denied. ${ }^{129}$ As noted above, many states have developed or adjusted legislation on juvenile justice in order to integrate children's rights standards. A growing body of regional and domestic jurisprudence is safeguarding a higher level of protection of children in conflict with the law (see section 2). Countries report institutional reform, such as the establishment of specialized juvenile justice tribunals or specialized services for children in conflict with the law. ${ }^{130}$ There is also a growing interest in the use of diversion-in some countries with a significant reduction of the number of children in the formal juvenile justice system as a result ${ }^{131}$-and in multidisciplinary approaches toward juvenile delinquency. Much more than before, juvenile justice reform can benefit from recent scientific insights in child development, brain development, effective juvenile justice interventions, and requirements for the effective participation of children in justice proceedings. ${ }^{132}$ And these insights confirm key juvenile justice principles, which have been embraced by international children's rights standards, such as the recognition that children are less culpable than adults, the acknowledgment that a fair, tailored, and child-specific pedagogical approach toward children in conflict with the law is more likely to have positive outcomes for both the child and society, and the need to protect children against the negative impact of the juvenile justice system and to support them in navigating through that system. ${ }^{133}$

\section{(p. 292) 4.2 Implementation of International Children's Rights: A Seri- ous Challenge in Different Ways}

At the same time, the implementation of international children's rights in the context of juvenile justice remains a serious challenge. ${ }^{134}$ The rights of children in conflict with the law are often not or not fully respected with negative consequences for their short- and long-term interests. ${ }^{135}$ As the CRC Committee observes, this is likely to have a negative impact on society's interests as well. ${ }^{136}$ Among others, there are persistent concerns about the widespread use of deprivation of their liberty and the way children deprived of liberty are being treated. Contrary to what international children's rights stipulate, deprivation of liberty is not used with the utmost restraint and for the shortest appropriate period of time. ${ }^{137}$ It has been reported that many children languish in pre-trial detention for months or even years ${ }^{138}$ and that states have difficulties in implementing adequate alternatives for arrest, detention, or imprisonment. ${ }^{139}$ In addition, children deprived of liberty 


\section{Juvenile Justice}

may not have access to basic services, such as sanitation, mental health care, or education; are not separated from adults and have little or no means of maintaining contact with family; run the risk of being subjected to various forms of violence, including disciplinary measures, such as solitary confinement; and have no access to justice. Many institutions in which children in conflict with the law are placed lack independent oversight. As a consequence, these children find themselves in a situation that makes them particularly vulnerable and dependent on the state and that puts them in serious jeopardy of having their rights disregarded or denied. ${ }^{140}$

Another issue of significant concern is the widespread occurrence of violence in the juvenile justice system. Since the 2006 UN violence study, which placed the issue of violence against children on the international agenda, different studies have reported on the various forms of violence committed against children in conflict with the law, that is: peer-topeer violence, self-harm or suicide, or violence committed against children by state actors, such as police officials, security forces, or staff of institutions. ${ }^{141}$ In 2012 the UN Special Representative on Violence against Children expressed her concern about the wide range of acts of violence against children throughout the juvenile justice system, from the first contact with law enforcement until the disposition of sentences. She concluded that an important strategy for the prevention of violence would be "preventing children from becoming involved with the juvenile justice system."142 In 2015 the UN Special Rapporteur on Torture expressed his grave concerns about torture and other forms of ill-treatment against children deprived of their liberty who are more vulnerable than adults and require a higher level of protection. ${ }^{143}$ Many states have difficulties or simply fail in protecting children against violence, a stark contrast to one of the cornerstones of international children's rights expressed in this oft-cited slogan: "All violence is preventable, and no violence is justifiable."144

The issues of deprivation of liberty and violence in the juvenile justice system show that the rights of children in conflict with the law are not always respected or adequately protected. This relates to a number of crosscutting challenges affecting children's rights (p. 293) implementation in the context of juvenile justice. ${ }^{145} \mathrm{~A}$ first challenge referred to in this regard could be called stigmatization. Children in and around the juvenile justice system, mainly adolescents, often belong to the most stigmatized groups of society, that is: children belonging to minorities, children in street situations, ${ }^{146}$ immigrant children, girls, ${ }^{147}$ and children in need of mental health or alternative care. Not only do these children suffer from racial discrimination, exclusion, or biases in their arrest, prosecution, sentencing, and treatment by law enforcement; ${ }^{148}$ they also may have special needs that do not get adequate attention, which affects their health and well-being. ${ }^{149}$ For these children, being in conflict with the law means they run the risk of being stigmatized even more. ${ }^{150}$

Second, juvenile justice is an area of controversy and heavily discussed and debated, despite the growing body of scientific knowledge on juvenile delinquency (and its decline ${ }^{151}$ ), adolescent development, and effective justice interventions. The way juvenile justice operates and is being regulated is significantly influenced by concerns, opinions, 


\section{Juvenile Justice}

perceptions, and stigmas around juvenile delinquency and public safety. Juvenile justice is affected by "zero tolerance" or "tough on crime" approaches, ${ }^{152}$ and used by politicians for political gain. ${ }^{153}$ In addition, misconceptions persist regarding the incidence and prevalence of juvenile delinquency, its impact on public safety, and effective strategies to prevent or respond to juvenile delinquency. ${ }^{154}$ A nuanced, evidence-based, children's rights-based construct of children in conflict with the law can be seriously challenged by the politicized nature of the debate around juvenile justice and the continuous pressure to address children's accountability when they commit a criminal offense, particularly when this offense is a serious one. Although one has to acknowledge that children do commit serious offenses, ${ }^{155}$ which may justify and even call for an intervention to protect public interests and/or interests of victims, the reality of stigmatization and controversy highlights a serious challenge for the implementation of children's rights and therefore requires states' full attention. ${ }^{156}$ For example, it has implications for sentencing policies and practices and can explain the use of harsh sentences resulting in institutionalization of children for long periods of time. The specific concerns expressed by the CRC Committee about juvenile justice systems that allow for (or mandate) a waiver or transfer of children to the adult criminal justice system should be understood also in light of the stigmatizing and controversial nature of juvenile justice. Although this practice can, according to the CRC Committee, be regarded as discriminatory because it excludes certain children from the protection of children's rights, it is widely used. ${ }^{157}$

A third crosscutting challenge for the implementation of international children's rights, providing universal standards for juvenile justice, relates to the differences among juvenile justice systems across the globe, ${ }^{158}$ differences in terms of their functioning, legal tradition, and meaning for fundamental juvenile justice concepts, such as accountability, pedagogical orientation, effective participation, proportionality, ${ }^{159}$ and in terms of the context in which juvenile delinquency manifests itself. Explanations for these differences can be found, among others, in the historical background of legal systems, ${ }^{160}$ in the availability of financial and human resources, and in social factors related to (p. 294) juvenile delinquency, including poverty, social exclusion, and stigmatization. ${ }^{161}$ Effective implementation of international children's rights requires the taking into account of the context in which a domestic justice system operates, which comes with a certain level of discretion under international children's rights law. At the same time, the international children's rights framework aims to protect all children in conflict with the law on the basis of principles that are assumed to have universal meaning and can be summarized as establishing children's entitlements to be treated fairly and in a child-specific manner (see section 3). Recognizing differences and discretion while upholding universal rights and principles makes implementation of children's rights in the context of juvenile justice not only a challenging endeavor but also a complex one. ${ }^{162}$ Two examples are provided below.

A first example concerns sentencing of children. Sentencing practices and approaches toward sentencing vary dramatically across the globe. ${ }^{163}$ The CRC has embraced this reality by granting states broad discretion on the matter, though it also provides for minimum standards-prohibiting capital punishment and corporal punishment as a sentence, 


\section{Juvenile Justice}

among others ${ }^{164}$-and a framework for sentencing revolving around the pedagogical orientation of juvenile justice (see section 3). With regard to imprisonment as a sentence for children, the CRC stipulates that it must be used as a last resort and for the shortest appropriate period of time, ${ }^{165}$ which seems to rule out mandatory or minimum sentences ${ }^{166}$ and calls for the use of alternatives. ${ }^{167}$ CRC Article 40(4) refers to the principle of proportionality, the application of which in the context of sentencing requires a tailored approach that takes into account "the circumstances and the gravity of the offence, but also ... the age, lesser culpability, circumstances and needs of the child, as well as ... the various and particularly long-term needs of the society." ${ }^{168}$ At the same time, it must be noted that CRC Article 37(a) allows for the use of life imprisonment as long as there is the possibility of parole. This is clearly one of weakest provisions in the CRC, which, as a result of a political compromise, ${ }^{169}$ shows the lack of willingness to accept that long custodial sentences cannot cohere with the pedagogical orientation of CRC Article 40(1) and with Article 37(b)'s requirement that deprivation of liberty shall be used only for the shortest appropriate period of time. ${ }^{170}$

International children's rights further oblige states to develop a legislative framework within which tailored decisions can be made and legal uncertainty and inequality prevented. This framework should also include procedural safeguards, such as the right to habeas corpus, ${ }^{171}$ and support the pedagogical orientation of juvenile justice, meaning that in the case of children, considerations of public safety and sanctions "must always be outweighed by the need to safeguard the well-being and the best interests of the child and to promote his/her reintegration," even in case of severe offenses. ${ }^{172}$ Tailored decision-making, however, implies that there will always be a certain risk for legal uncertainty, inequality, or even bias, which explains why the CRC Committee underscores the importance of respecting the CRC's general principles, in particular CRC Article 2, prohibiting discrimination. ${ }^{173}$ Decisions on the use of alternatives to imprisonment depend, among other things, on the availability of human and financial resources, domestic legislation that encourages the use of alternatives, and the willingness of (p. 295) decision makers to apply alternatives. Whether decision makers utilize such alternatives depends in part on their knowledge of and sensitivity to children's rights, which suggests that juvenile justice policies should also include targeted training of decision makers. ${ }^{174}$

A second example illustrating the complexity of children's rights implementation concerns the minimum age of criminal responsibility (MACR). The CRC Committee provides that states should set a MACR. ${ }^{175}$ It does not, however, provide what the MACR should be, and there is no consensus among states from which age children can and should be held accountable. ${ }^{176}$ As was recognized by the drafters of the Beijing Rules, "the minimum age of criminal responsibility differs widely owing to history and culture" and "[t]he modern approach would be to consider whether a child can live up to the moral and psychological components of criminal responsibility; that is whether a child, by virtue of her or his individual discernment and understanding, can be held responsible for essentially antisocial behaviour." 177 Consequently, Rule 4.1 of the Beijing Rules provides that the MACR "shall not be fixed at too low an age level, bearing in mind the facts of emotional, mental and intellectual maturity." Despite the lack of international consensus, the CRC 


\section{Juvenile Justice}

Committee has decided to recommend using a MACR of at least twelve years "as the absolute minimum age." ${ }^{178}$ An age limit below that, according to the CRC Committee, would not be "internationally acceptable," and it is recommended that the minimum age be raised "to a higher level." ${ }^{179}$ As a consequence, states parties should not lower their age to twelve, and the CRC Committee seems to suggest that a MACR of fourteen or sixteen should be favored instead. It is interesting to see that there are states that have raised their age to a higher level (i.e., not necessarily to the age of twelve yet) and that some are in the process of doing so, in part due to the recommendations made by the CRC Committee. ${ }^{180} \mathrm{~A}$ small number of states, however, have lowered their MACR, and some states are considering doing so in the future. ${ }^{181}$ This shows, on the one hand, the support for the international standard carried out by the CRC Committee, ${ }^{182}$ which aims to shield younger children from prosecution and to guarantee older children the fair and child-specific treatment to which they are entitled. ${ }^{183}$ At the same, the lowering or attempts to lower the MACR in some countries suggests that the implementation of children's rights in the context of juvenile justice systems can easily be pushed back in times of hostile political headwinds. ${ }^{184}$

\section{Conclusion}

Juvenile justice is clearly a children's rights issue. The comprehensive international legal framework obliges states, as the primary duty bearers, to protect the rights and interests of each child in conflict with the law, in a system that is, above all, focused on the protection of the interests of society and others. States have a lot discretion, which calls for legislation at the domestic level and investment in the quality of its application, for which specialized professionals who are sensitive to children's rights are key. ${ }^{185}$ Moreover, juvenile justice reform requires coordination and leadership as well as an approach that

(p. 296) makes children visible and places them at the heart of the system, building on the recognition that children in conflict with the law are above all children with children's rights. It is clear that the juvenile system is a rather difficult context in which children's rights must find their way. The implementation gap may justify the conclusion that children's rights in juvenile justice will always remain a utopian dream. Drawing this conclusion, however, would disregard the enormous progress made in the past thirty years and the efforts and investments of many. Therefore, it is important to remain hopeful and to continue to work on the diverse challenges children's rights implementation face in the specific context of juvenile justice.

\section{Acknowledgment}

The author wishes to thank Chris Sandelowsky, LL.M., for her assistance. 


\section{Notes:}

(1.) This chapter refers to the child in conflict with the law as a child (i.e., in principle, a person under the age of eighteen; CRC Article 1) who is alleged as, accused of, or recognized as having infringed the domestic penal law.

(2.) UN Convention on the Rights of the Child (CRC), G.A. Res. 44/25, 44th Sess., UN Doc. A/RES/44/25 (1989).

(3.) Where this chapter refers to he, she is meant as well, unless stated otherwise.

(4.) See, e.g., Elizabeth Scott and Laurence Steinberg, Rethinking Juvenile Justice (Cambridge, MA: Harvard University Press, 2008).

( $\left.{ }^{5 .}\right)$ Roper v. Simmons, 543 U.S. 551 (2005).

(6.) Roper.

(7.) Jean Trépanier, “Children's Rights in Juvenile Justice: A Historical Glance," in The UN Children's Rights Convention: Theory Meets Practice, ed. André Alen, Henry Bosly, Maria De Bie, Johan Vande Lanotte, Fiona Ang, Isabelle Delens-Ravier, Marie Delplace, Charlotte Herman, Didier Reynaert, Valentina Staelens, Riet Steel, and Mieke Verheyde (Mortsel, BE: Intersentia, 2007), 509-530.

(8.) Geneva Declaration of the Rights of the Child, adopted by the League of Nations on September 26, 1924.

(9.) UN Standard Minimum Rules for the Administration of Juvenile Justice (Bejing Rules), G.A. Res. 40/33, 40th Sess., UN Doc. A/RES/40/33 (1985); Sharon Detrick, A Commentary on the United Nations Convention on the Rights of the Child (The Hague: Kluwer Law International, 1999), 681.

(10.) CRC, arts. 2, 3(1), 6, and 12; UN Committee on the Rights of the Child (CRC Committee), General Comment No. 5: General Measures of Implementation of the Convention on the Rights of the Child (arts. 4, 42 and 44, para. 6), UN Doc. CRC/GC/2003/5 (2003), para. 12 .

(11.) UN Rules for the Protection of Juveniles Deprived of Their Liberty (Havana Rules), G.A. Res. 45/113, 45th Sess., UN Doc. A/RES/45/113 (1990).

(12.) United Nations Office of the High Commissioner for Human Rights (OHCHR), "Guidelines for the Prevention of Juvenile Delinquency" (The Riyadh Guidelines), G.A. Res. 45/112, 45th Sess., UN Doc. A/RES/45/112 (Dec. 14, 1990).

(13.) Havana Rules, Rule 3.

(14.) Riyadh Guidelines, Guideline I.3. 
(15.) CRC Committee, “General Comment No. 10: Children's Rights in Juvenile Justice,” UN Doc. CRC/C/GC/10 (2007), paras. 4, 8 and 17.

(16.) CRC Committee, “General Comment No. 10,” paras. 32, 46, 66 and 89.

(17.) CRC Committee, “General Comment No. 10,” para. 88.

(18.) See, e.g., European Union Agency for Fundamental Rights and Council of Europe, Handbook on European Law Relating to the Rights of the Child (Luxembourg: Publications Office of the European Union, 2017); Ganguly E. Thukral and A. Kumar Asthana, "Children's Rights in Litigation: Use of the CRC in Indian Courts," in Litigating the Rights of the Child: The U.N. Convention on the Rights of the Child in Domestic and International Jurisprudence, ed. Ton Liefaard and Jaap Doek ed. Ton Liefaard and Jaap Doek. (The Hague: Springer Netherlands, 2015), 39 and 41; Ann Skelton, "Child Justice in South Africa: Application of International Instruments in the Constitutional Court," International Journal of Children's Rights 26, no.3 (August 2018): 391-442; Monica Feria-Tinta, "The CRC as a Litigation Tool before the Inter-American System of Protection of Human Rights," in Liefaard and Doek, Litigating the Rights of the Child, 238.

(19.) See also CRC, art. 41.

(20.) International Covenant on Civil and Political Rights (ICCPR), G.A. Res. 2200A (XXI), 21st Sess., UN Doc. A/6316 (1966).

(21.) Detrick, Commentary on the United Nations Convention on the Rights of the Child, 622,629 , and 682 .

(22.) Convention against Torture and Other Cruel, Inhuman or Degrading Treatment or Punishment, G.A. Res. 39/46, 39th Sess., UN Doc. A/RES/39/46 (1984).

(23.) International Convention on the Elimination of All Forms of Racial Discrimination, G.A. Res. 2106 (XX), 20th Sess., UN Doc. A/6014 (1965).

(24.) The Nelson Mandela Rules are a revised version of the 1955 UN Standard Minimum Rules for the Treatment of Prisoners, GA Res. 663 C (XXIV), A/RES/663 C (XXIV) (1957), and ECOSOC Res. 2076 (LXII) (1977).

(25.) UN Convention on the Rights of the Child (CRC), G.A. Res. 45/110, 68th Sess., A/ RES/45/110 (1990).

(26.) See, e.g., American Convention on Human Rights (ACHR), 36 O.A.S.T.S. (Nov 22, 1969; entered into force July, 18, 1979), arts. 5(5) and 19; and European Convention on Human Rights, European Convention for the Protection of Human Rights and Fundamental Freedoms, 213 UNTS 221 (Nov. 4, 1950; entered into force Sept. 3, 1953), arts. 5 and 6. 
(27.) Feria-Tinta, "CRC as a Litigation Tool”; Inter-American Commission on Human Rights, "Juvenile Justice and Human Rights in the Americas," OEA/Ser.L./V/II (July 13, 2011), http://www.cidh.org/countryrep/JusticiaJuvenileng/jjsummary.eng.htm. See also Bernardine Dohrn, "Something's Happening Here: Children and Human Rights Jurisprudence in Two International Courts," Nevada Law Journal 6, no. 3 (2006): 749-773.

(28.) Case of the "Street Children" (Villagran-Morales et al.) v. Guatemala, Inter-American Court of Human Rights (Nov. 19, 1999), para. 189.

(29.) Villagran-Morales et al., paras. 190-191.

(30.) Villagran-Morales et al., para. 194.

(31.) Villagran-Morales et al., para. 196 (with reference to CRC arts. 2, 3(2), 6, 20, 27, and 37 (para. 195)). The Court also referred to the Riyadh Guidelines and Beijing Rules, para. 197.

(32.) Feria-Tinta, “CRC as a Litigation Tool,” 247.

(33.) Feria-Tinta, "CRC as a Litigation Tool," 239 (with reference to Inter-American Commission on Human Rights, Children and Their Rights, para. 53).

(34.) Council of Europe Committee of Ministers, "Recommendation

Rec(2003)20:Concerning New Ways of Dealing with Juvenile Delinquency and the Role of Juvenile Justice" (Sept. 24, 2003).

(35.) Council of Europe Committee of Ministers, "Recommendation Rec(2008)11 on the European Rules for Juvenile Offenders Subject to Sanctions or Measures” (Nov. 5, 2008), https://www.unicef.org/tdad/councilofeuropejjrec08(1).pdf.

(36.) Committee of Minsters of the Council of Europe, "Guidelines of the Committee of Ministers of the Council of Europe on Child-Friendly Justice" (Nov. 17, 2010), 13, www.coe.int/childjustice.

(37.) See Ursula Kilkelly, "CRC in Litigation under the ECHR," in Liefaard and Doek, Litigating the Rights of the Child; and Ton Liefaard and Ursula Kilkelly, "Child-Friendly Justice: Past, Present and Future," in Juvenile Justice in Europe: Past, Present and Future, ed. Barry Goldson (New York: Routledge, 2018).

(38.) Liefaard and Kilkelly, “Child-Friendly Justice.” See, e.g., Blokhin v. Russia, Application No. 47152/06, Eur. Ct. H. R., GC (March 23, 2016), paras. 170 and 203.

(39.) The European Parliament and Council, “Directive (EU) 2016/800 of the European Parliament and of the Council of 11 May 2016 on procedural safeguards for children who are suspects or accused persons in criminal proceedings," https://eur-lex.europa.eu/legalcontent/EN/TXT/?uri=CELEX\%3A32016L0800. See also Stephanie Rap and Daniella Zlotnik, "The Right to Legal and Other Appropriate Assistance for Child Suspects and Ac- 


\section{Juvenile Justice}

cused," European Journal of Crime, Criminal Law, and Criminal Justice 26, no. 2 (May 2018): 110-131.

(40.) The African Committee of Experts on the Rights and Welfare of the Child and the African Union et al, "Guidelines on Action for Children in the Justice System in Africa" (2011), and "The Munyonyo Declaration on Child Justice in Africa" (final version Jan. 24, 2012), http://www.kampalaconference.info (accessed Aug. 19, 2019). See also the International Association of Youth and Family Judges and Magistrates (AYFJM), "Guidelines on Children in Contract with the Justice System" (adopted Oct. 21, 2016; ratified April 26, 2017), http://www.aimjf.org/storage/www.aimjf.org/Documentation_EN/AIMJF/ Guidelines_-_ENG_-_Ratified_17.04.26.pdf (developed on the basis of the child-friendly justice guidelines and their equivalents in Africa and Latin America). The IAYFJM guidelines use the term "child focussed justice" (see page 11), which the IAYFJM deemed more appropriate in relation to the context of juvenile justice.

(41.) See Salduz v. Turkey, Application No. 36391/02, Eur. Ct. H.R. 27 (November 2008); Panovits v. Cyprus, Application No. 4268/04, Eur. Ct. H.R 11 (December 2008).

(42.) See, e.g., Güveç v. Turkey, Application No. 70337/01, Eur. Ct. H.R. (Jan. 20, 2009), and Korneykova v. Ukraine, Application No. 39884/05, Eur. Ct. H.R. (Jan. 19, 2012).

(43.) See, e.g., Güveç; and Nart v. Turkey, Application No. 20817/04, Eur. Ct. H.R. (May 6, 2008); see also Blokhin.

(44.) European Union Agency for Fundamental Rights and Council of Europe, Handbook on European Law Relating to the Rights of the Child.

(45.) European Committee for the Prevention of Torture and Inhuman or Degrading Treatment or Punishment (CPT), “24th General Report of the CPT," CPT/Inf 20151 (January 2015).

(46.) CRC Committee, “General Comment No. 10,” para. 3.

(47.) See, e.g., Julia L. Sloth-Nielsen, “The Influence of International Law on South Africa's Juvenile Justice Reform Process," LLD thesis, University of the Western Cape, 2001; UNICEF Innocenti Research Centre, Law Reform and the Implementation of the Convention on the Rights of the Child (Florence: UNICEF Innocenti Research Centre, 2007); Laura Lundy, Ursula Kilkelly, Bronagh Bryne, and Jason Kang, "The UN Convention on the Rights of the Child: A Study of Legal Implementation in 12 Countries," Centre for Children's Rights School of Education, Queen's University Belfast (November 2012), http://www.qub.ac.uk/research-centres/CentreforChildrensRights/filestore/Filetoupload, 453628,en.pdf\#search=The\%20UN\%20Convention\%20on\%20the\%20Rights\%20of\%20the\%20Child Raoul Wallenberg Institute, "A Measure of Last Resort? The Current Status of Juvenile Justice in ASEAN Member States" (April 2015), https://rwi.lu.se/app/uploads/2015/04/Juvenile-Justice-Report.pdf; Franklin Zimring, Maximo Langer, and David Tanenhaus, Juvenile Justice in Global Perspective (New York: NYU Press, 2015). 


\section{Juvenile Justice}

(48.) See, e.g., Liefaard and Doek, Litigating the Rights of the Child, and Skelton, "Child Justice in South Africa."

(49.) These groups include the Human Rights Council, the Office of the High Commissioner for Human Rights (OHCHR), the UN Office on Drugs and Crime (UNODC), the UN Special Representative on Violence against Children, UNICEF, the Inter-American Commission on Human Rights, the Council of Europe.

(50.) See, for example, the former Inter-Agency Panel on Juvenile Justice, International Juvenile Justice Observatory (IJJO), Defence for Children International, Penal Reform International (PRI), and Human Rights Watch.

(51.) This paragraph is partly based on Ton Liefaard, "Juvenile Justice from a Children's Rights Perspective," in The Routledge International Handbook of Children's Rights Studies, ed. Wouter Vandenhole, Ellen Desmet, Didier Reynaert, and Sara Lembrechts (London: Routledge, 2015).

(52.) Liefaard, “Juvenile Justice from a Children's Rights Perspective.”

(53.) CRC Committee, “General Comment No. 10,” para. 10.

(54.) See CRC art. 29(1)(b) and CRC Committee, “General Comment No. 10.”

(55.) CRC Committee, “General Comment No. 10,” para. 10.

(56.) CRC Committee, “General Comment No. 10," paras. 16 and 17. See also Riyadh Guidelines and Council of Europe Committee of Ministers, "Recommendation Rec(2003) 20."

(57.) CRC Committee, “General Comment No. 10,” paras. 6-8.

(58.) CRC Committee, "General Comment No. 10," para. 8; see also Riyadh Guidelines, Guideline VI.56, and CRC Committee, "General Comment No. 21: Children in Street Situations," UN Doc. CRC/C/GC/21 (2017).

(59.) Jaap Doek, “Juvenile Justice: International Rights and Standards," in Criminals. The Development of Child Delinquency and Effective Interventions, ed. N. Wim Slot, Machteld Hoeve, and Rolf Loeber (London: Routledge, 2008), 236.

(60.) For more on the controversies around the MACR see Liefaard, "Juvenile Justice from a Children's Rights Perspective."

(61.) CRC, art. 40(3)(b). The UN Committee on the Rights of the Child underscores that diversion should not be reserved for first offenders only; recidivist and even serious offenders should also have access to appropriate diversion programs. CRC Committee, "General Comment No. 10," paras. 23 and 25. 
(62.) CRC Committee, "General Comment No. 10," para. 25. Diversion also is considered as potentially more cost-effective. See Frieder Dünkel, "Diversion: A Meaningful and Successful Alternative to Punishment in European Juvenile Justice System," in Reforming Juvenile Justice, ed. Josine Junger-Tas and Frieder Dunkel (New York: Springer-Verlag. 2009), 147.

(63.) CRC Committee, “General Comment No. 10,” para. 27.

(64.) CRC Committee, “General Comment No. 10,” paras. 24-26.

(65.) CRC Committee, “General Comment No. 10,” para. 27.

(66.) CRC Committee, “General Comment No. 10," para. 27. See also United Nations Children's Fund (UNICEF), "Diversion Not Detention: A Study in Diversion and Other Alternative Measures for Children in Conflict with the Law in East Asia and the Pacific" (March 2018), https://www.unicef.org/eap/reports/diversion-not-detention; and UN Special Representative of the Secretary-General on Violence against Children, "Promoting Restorative Justice for Children," Office of the SRSG on Violence against Children (2013), https://sustainabledevelopment.un.org/index.php?

page $=$ view\&type $=400 \& n r=2599 \&$ menu $=1515$.

(67.) Note that CRC, art. 40(1), does not refer to maturity, but arguably this can be read into the text of the convention, also in light of other provisions referring to the developmental dynamics regarding children; see, e.g., CRC, arts. 5 and 12.

(68.) See CRC, arts. 18 and 5.

(69.) CRC, art. 37(c); see also Havana Rules, Rule 11a (calling for the establishment of a minimum age of deprivation of liberty). See also Council of Europe, "Commentary to the European Rules for Juvenile Offenders Subject to Sanctions or Measures," CM(2008)128 (2008), addendum 1, 47, https://www.unicef.org/tdad/ councilofeuropejjrec08commentary(1).pdf.

(70.) Liefaard, “Juvenile Justice from a Children’s Rights Perspective.”

(71.) UNICEF Innocenti Research Centre, Law Reform and Implementation.

(72.) Ineke Pruin, “The Scope of Juvenile Justice Systems in Europe," in Juvenile Justice Systems in Europe-Current Situation and Reform Developments, ed. Frieder Dünkel, Joanna Grzywa, Phillip Horsfield, and Ineke Pruin, 2nd ed. (Mönchengladbach, DE: Forum-Verlag, 2011), 1523-1525.

(73.) Liefaard, “Juvenile Justice from a Children's Rights Perspective.” See also Lundy et al., "UN Convention on The Rights of the Child," and UNICEF Innocenti Research Centre, Law Reform and Implementation.

(74.) CRC Committee, “General Comment No. 10,” para. 4. 
(75.) CRC Committee, “General Comment No. 5,” para. 12.

(76.) CRC Committee, “General Comment No. 10,” para. 92; see also, e.g., Beijing Rules 12.1 .

(77.) Detrick, Commentary on the United Nations Convention of the Rights of the Child, 633.

(78.) Ton Liefaard, Deprivation of Liberty of Children in Light of International Human Rights Law and Standards (Cambridge, UK: Intersentia, 2008).

(79.) This exception should be understood in light of CRC Article 3(1) as one of the key concepts of international children's rights law and one of the CRC's general principles (identified as such by the CRC Committee). This exception has also been included because of the fact that the stricter approach under ICCPR Article 10 (i.e., separation/segregation without any exceptions) has resulted in quite a number of reservations. Liefaard, Deprivation of Liberty of Children.

(80.) See Liefaard, Deprivation of Liberty of Children.

(81.) CRC Committee, “General Comment No. 10,” para. 13.

(82.) CRC Committee, “General Comment No. 10,” para. 13.

(83.) Detrick, Commentary on the United Nations Convention of the Rights of the Child. See also ECHR, arts. 6 and 7, and ACHR, arts. 8 and 9.

(84.) CRC, art. 40(2)(b)(i).

( ${ }^{85 .)}$ CRC, art. 40(2)(b)(iv).

(86.) CRC, art. 40(2)(b)(ii).

(87.) CRC, art. 40(2)(b)(iii). There is also the right to appeal-see CRC, art. 40(2)(b)(v), and ICCPR, art. 14(5).

(88.) CRC, art. 40(2)(b)(iv).

(89.) CRC, art. 40(2)(b)(iv).

(90.) CRC, art. 40(2)(b)(iii).

(91.) Compare ICCPR, art. 14(2)(c), and ECHR, art. 6(1).

(92.) CRC Committee, “General Comment No. 10,” para. 51.

(93.) CRC Committee, “General Comment No. 10,” para. 51.

(94.) CRC, art. 40(2)(b)(vii); see also CRC, art. 16.

(95.) CRC Committee, “General Comment No. 10,” para. 65. 
(96.) CRC Committee, “General Comment No. 10,” para. 67.

(97.) CRC Committee, “General Comment No. 10,” para. 47.

(98.) See CRC Committee, “General Comment No. 10," para. 47. See also Committee of Ministers of the Council of Europe, "Guidelines of the Committee of Ministers of the Council of Europe on Child-Friendly Justice."

(99.) See CRC, arts. 18 and 5; see also the CRC's preamble.

(100.) See also Beijing Rules 15.2 and 18.2.

(101.) CRC, art. 40(2)(b)(iii).

(102.) See Salduz; Panovits. This right has recently been incorporated in European Union legislation. See Rap and Zlotnik, "Right to Legal and Other Appropriate Assistance for Child Suspects and Accused."

(103.) CRC Committee, “General Comment No. 10,” para. 49.

(104.) T. Liefaard and Yannick Van den Brink, “Juveniles' Right to Counsel during Police Interrogations: An Interdisciplinary Analysis of a Youth-Specific Approach, with a Particular Focus on the Netherlands," Erasmus Law Review, 7 no. 4 (2014): 206-218.

(105.) CRC Article 40(3)(b) underscores that in case of diversion the human rights of and legal safeguards for children must be fully respected; see also CRC Committee, "General Comment No. 10," paras. 22 and 27.

(106.) CRC Committee, “General Comment No. 10,” para. 50.

(107.) Geraldine Van Bueren, A Commentary on the United Nations Convention on the Rights of the Child, Article 40: Child Criminal Justice (Leiden: Martinus Nijhoff Publishers 2006), 19.

(108.) CRC Committee, “General Comment No. 10,” para. 49.

(109.) Liefaard and Van den Brink, “Juveniles' Right to Counsel.” Mandatory legal assistance, which excludes children from waiving this right, was included by the European Commission in its proposal for the EU directive on procedural safeguards for children suspected or accused in criminal proceedings; see https://eur-lex.europa.eu/legal-content/ EN/TXT/?uri=CELEX\%3A52013PC0822. The adopted text of the EU directive leaves room for EU member states not to provide for legal counsel if this is regarded disproportionate. See also Rap and Zlotnik, "Right to Legal and Other Appropriate Assistance for Child Suspects and Accused."

(110.) CRC, art. 37(d). 
(111.) T. v. the United Kingdom, Application No. 24724/94, Eur. Ct. H.R. (Dec. 16, 1999); see also V. v. the United Kingdom, Application No. 24888/94, Eur. Ct. H.R. (Dec. 16, 1999). See also Kilkelly, "CRC in Litigation under the ECHR," and Liefaard and Kilkelly, "Child-Friendly Justice."

(112.) T., para. 84 .

(113.) T., para. 88 .

(114.) S.C. v. the United Kingdom, Application No. 60958/00, Eur. Ct. H.R. (June 15, 2004), para. 29. This court also pointed at the significance of legal representation in this regard.

(115.) CRC Committee, “General Comment No. 10," para. 46 (with reference to CRC Article 12(2)). See also CRC Committee, "General Comment No. 12: The Right of the Child to be Heard," UN Doc. CRC/C/GC/12 (2009).

(116.) Kilkelly, “CRC in litigation under the ECHR." See also Liefaard and Kilkelly, “ChildFriendly Justice."

(117.) CRC Committee, “General Comment No. 10,” para. 12.

(118.) CRC Committee, “General Comment No. 10,” para. 46.

(119.) CRC Committee, “General Comment No. 12,” para. 34.

(120.) CRC Committee, “General Comment No. 12,” para. 34.

(121.) CRC Committee, “General Comment No. 12,” paras. 60-61.

(122.) Stephanie Rap, "The Participation of Juvenile Defendants in the Youth Court: A Comparative Study of Juvenile Justice Procedures in Europe," PhD diss. (Utrecht University, 2013); Stephanie Rap, “A Children's Rights Perspective on the Participation of Juvenile Defendants in the Youth Court," International Journal of Children's Rights 24, no. 1 (2016): 93-112. See also Aoife Daly and Stephanie Rap, "Children's Participation in the Justice System," in International Human Rights of Children, ed. Ursula Kilkelly and Ton Liefaard (Singapore: Springer, 2018), 299-319.

(123.) See Liefaard and Kilkelly, “Child-Friendly Justice”

(124.) According to the guidelines: “'[C]hild-friendly justice' refers to justice systems which guarantee the respect and the effective implementation of all children's rights at the highest attainable level, bearing in mind the principles listed below and giving due consideration to the child's level of maturity and understanding and the circumstances of the case. It is, in particular, justice that is accessible, age appropriate, speedy, diligent, adapted to and focused on the needs and rights of the child, respecting the rights of the child including the rights to due process, to participate in and to understand the proceedings, to respect for private and family life and to integrity and dignity." See Committee of 


\section{Juvenile Justice}

Ministers of the Council of Europe, "Guidelines of the Committee of Ministers of the Council of Europe on Child-Friendly Justice," II(c).

(125.) For more on the drafting and the added value of the guidelines see Liefaard and Kilkelly, "Child-Friendly Justice"; and Council of Europe Directorate General on Human Rights and Legal Affairs, Group of Specialists on Child-Friendly Justice, "Listening to Children about Justice: Report of the Council of Europe's Consultation with Children on Child-Friendly Justice” (Oct. 5, 2010). See also Directorate-General for Justice and Consumers (European Commission), "Children's Involvement in Criminal, Civil and Administrative Judicial Proceedings in the 28 Member States of the EU," policy brief (July 7, 2015).

(126.) See, e.g., Rap, "Participation of Juvenile Defendants in the Youth Court.”

(127.) See European Commission, "Summary of Contextual Overviews on Children's Involvement in Criminal Justice Proceedings in the 28 Member States of the European Union" (April 16, 2014); Liefaard and Kilkelly, "Child-Friendly Justice"; European Commission, "Children's Involvement in Criminal, Civil and Administrative Judicial Proceedings in the 28 Member States of the EU."

(128.) See, e.g., M.J. Bernuz Beneitez and E. Dumortier, "Why Children Obey the Law: Rethinking Juvenile Justice and Children's Rights in Europe through Procedural Justice," Youth Justice 18, no. 1 (2018): 34-51.

(129.) UNICEF Innocenti Research Centre, Law Reform and Implementation. See also UNICEF Innocenti Research Centre, Juvenile Justice Innocenti Digest No. 3 (Florence, UNICEF International Child Development Centre, 1998); Zimring, Langer, and Tanenhaus, Juvenile Justice in Global Perspective; Barry Goldson and John Muncie, "Towards a Global 'Child-Friendly' Juvenile Justice?," International Journal of Law Crime and Justice 40, no. 1 (January 2012): 47-64.

(130.) See, e.g., specific studies on China, South Africa, and Latin-America in Zimring, Langer and Tanenhaus, Juvenile Justice in Global Perspective.

(131.) See, e.g., Georgia. See UNICEF Innocenti Research Centre, Juvenile Justice Innocenti Digest no. 3; UNICEF, "Diversion not Detention”; Raoul Wallenberg Institute, "Measure of Last Resort?"

(132.) See Scott, Elizabeth S. and Steinberg, Laurence, Rethinking Juvenile Justice; see also Scott, Elizabeth, Thomas Grisso, Marsha Levick, and Laurence Steinberg. 2016. "Juvenile Sentencing Reform in a Constitutional Framework.” Temple Law Review 88: 675-716.

(133.) Rap, "Participation of Juvenile Defendants in the Youth Court."

(134.) See, e.g., Raoul Wallenberg Institute, “A Measure of Last Resort?” 
(135.) See, e.g., OHCHR, "Joint Report of the Office of the High Commissioner for Human Rights, the United Nations Office on Drugs and Crime and the Special Representative of the Secretary-General on Violence against Children on Prevention of and Responses to Violence against Children within the Juvenile Justice System," UN Doc. A/HRC/21/25 (June 27, 2012).

(136.) CRC Committee, “General Comment No. 10,” para. 3.

(137.) CRC, art. 37 (b).

(138.) CRC Committee, “General Comment No. 10,” para. 80.

(139.) See CRC, art. 40(4) (mentions "care, guidance and supervision orders; counselling; probation; foster care; education and vocational training programmes and other alternatives to institutional care" as alternative dispositions).

(140.) United Nations Secretary-General, "Report of the Independent Expert for the United Nations Study on Violence against Children," UN Doc. A/61/299 (Aug. 29, 2006). See also OHCHR, "Joint Report on Violence against Children"; Barry Goldson and Ursula Kilkelly, "International Human Rights Standards and Child Imprisonment: Potentialities and Limitations," International Journal of Children's Rights 21, no. 2 (January 2013): 345371; Center for Human Rights and Humanitarian Law, Protecting Children against Torture in Detention: Global Solutions for a Global Problem (Washington, DC: American University Washington College of Law, 2017); OHCHR, "Children Deprived of Liberty: The United Nations Global Study,” http://www.ohchr.org/EN/HRBodies/CRC/StudyChildrenDeprivedLiberty/Pages/Index.aspx (accessed Aug. 20, 2019).

(141.) See, e.g., United Nations Secretary-General, "Report of the Independent Expert for the United Nations Study on Violence against Children"; OHCHR, "Joint Report on Violence against Children"; Ton Liefaard, "Report on Violence in Institutions for Juvenile Offenders," PC-CP\docs 2014\PC-CP(2014)13e rev2, European Council (Nov. 7, 2014). See also the case law of the Inter-American Court referred to in section 2.

(142.) OHCHR, “Joint Report on Violence against Children,” para. 66.

(143.) Center for Human Rights and Humanitarian Law, Protecting Children against Torture in Detention.

(144.) United Nations Secretary-General, "Report of the Independent Expert for the United Nations Study on Violence against Children."

(145.) See, e.g., OHCHR, “Joint Report on Violence against Children," para. 9.

(146.) See, e.g., CRC Committee, “General Comment No. 21.”

(147.) A group of children currently receiving the attention of the international community is made up of children associated with violent extremism; see, e.g., UN Office on Drugs and Crime, "Handbook on Children Recruited and Exploited by Terrorist and Violent Ex- 


\section{Juvenile Justice}

tremist Groups: The Role of the Justice System," (2017), https://www.unodc.org/documents/justice-and-prison-reform/Child-Victims/

Handbook_on_Children_Recruited_and_Exploited_by_Terrorist_and_Violent_Extremist_Groups_the_R

(148.) See, e.g., Nancy Dowd, Reimagining Equality: A New Deal for Children of Color (New York: NYU Press, 2018). See also OHCHR, “Joint Report on Violence against Children."

(149.) See, e.g., Liefaard, “Report on Violence in Institutions for Juvenile Offenders.”

(150.) See, e.g., Office of the Special Representative of the Secretary-General on Violence against Children, "Safeguarding the Rights of Girls in the Criminal Justice Sys-

tem," (2007), https:/violenceagainstchildren.un.org/sites/violenceagainstchildren.un.org/ files/document_files/safeguarding_the_rights_of_girls_in_the_criminal_justice_system: 1.pdf.

(151.) See, e.g., Leslie McAra and Susan McVie, "Transformations in Youth Crime and Justice across Europe: Evidencing the Case for Diversion," in Goldson, Juvenile Justice in Europe, 74-104.

(152.) Roger Smith, Youth Justice: Ideas, Policy, Practice, 3rd ed. (New York: Routledge, 2013). See also Michael Cavadino and James Dignan, Penal Systems: A Comparative Approach (London: Sage, 2005).

(153.) David Downes and Rod Morgan, "Waiting for Ingleby: The Minimum Age of Criminal Responsibility-A Red Line Issue?," in Policing: Politics, Culture, and Control, ed. Tim Newburn and Jill Peay (Oxford, UK: Hart Publishing, 2011), 245-264. See also John Muncie, Youth \& Crime, 4th ed. (London: Sage Publications, 2015). And see Wendy O’Brien and Kate Fitz-Gibbon, "Can Human Rights Standards Counter Australia's Punitive Youth Justice Practices?," International Journal of Children's Rights 26, no. 2 (2018): 197-227.

(154.) See CRC Committee, “General Comment No. 10,” para. 96.

(155.) Nessa Lynch, "Towards a Principled Legal Response to Children Who Kill," Youth Justice 18 no. 3 (2018): 211-229.

(156.) CRC Committee, “General Comment No. 10," para. 96. It also implicates the role of media.

(157.) CRC Committee, “General Comment No. 10.” para. 38.

(158.) Cavadino and Dignan, Penal Systems. See also Don Cipriani, Children's Rights and the Minimum Age of Criminal Responsibility: A Global Perspective (Farnham, UK: Ashgate, 2009). See also Rap, "Participation of Juvenile Defendants in the Youth Court."; Goldson and Muncie, "Towards a Global 'Child-Friendly' Juvenile Justice?”; Zimring, Langer, and Tanenhaus, Juvenile Justice in Global Perspective. 


\section{Juvenile Justice}

(159.) A simplified distinction can be made between welfare systems, which focus primarily on care, protection, and treatment of children in conflict with the law and less on rights and freedoms, and justice systems, which focus primarily on competence and accountability of children but also include attention for rights and freedoms and proportionality; see Muncie, Youth \& Crime. See also Jenneke Christiaens, It's for Your Own Good: Researching Youth Justice Practices (Brussels: Vubpress, 2015); Raymond Arthur, The Moral Foundations of The Youth Justice System (New York: Routledge, 2017). It can be argued that the CRC essentially combines elements of both models.

(160.) See, e.g., Cipriani, Children's Rights and the Minimum Age of Criminal Responsibility.

(161.) See, e.g., Leslie McAra and Susan McVie, "Understanding Youth Violence: The Mediating Effects of Gender, Poverty and Vulnerability," Journal of Criminal Justice 45 (February 2016): 71-77; and Barry Goldson, "Reading the Present and Mapping the Future(s) of Juvenile Justice in Europe: Complexities and Challenges," in Goldson, Juvenile Justice in Europe, 209-253.

(162.) See also, e.g., Goldson and Muncie, “Towards a Global ‘Child-Friendly’ Juvenile Justice?"

(163.) Frieder Dünkel, "Sanctions Systems and Trends in the Development of Sentencing Practices," in Juvenile Justice Systems in Europe: Current Situation, Reform Developments, and Good Practices (Mönchengladbach, DE: Forum Verlag Godesberg, 2018). See also Zimring, Langer, and Tanenhaus, Juvenile Justice in Global Perspective.

(164.) CRC, art. 37(a) CRC Committee, “General Comment No. 10,” para. 71 (with reference to CRC Committee, "General Comment No. 8").

(165.) CRC, art. 37(b).

(166.) See, e.g., Centre for Child Law v. Minister of Justice, 2009 (6) SA 632 (CC).

(167.) CRC, art. 40(4).

(168.) CRC Committee, “General Comment No. 10,” para. 71.

(169.) Detrick, Commentary on the United Nations Rights of the Child.

(170.) CRC Committee, “General Comment No. 10,” para. 77.

(171.) See, e.g., CRC, art. 37(d).

(172.) CRC Committee, “General Comment No. 10,”, para. 71.

(173.) CRC Committee, “General Comment No. 10,” para. 6. 
(174.) CRC Committee, "General Comment No. 10"; compare Y. N. van den Brink, "Voorlopige hechtenis in hetnederlandse jeugdstrafrecht: wet en praktijk in het licht van internationale en Europese kinder-en mensenrechten," PhD diss., Leiden University, 2018.

(175.) Despite the rather weakly formulated provision, the UN Committee on the Rights of the Child understands it as an obligation for states parties to set a MACR. See CRC Committee, “General Comment No. 10," para. 31.

(176.) Cipriani, Children's Rights and the Minimum Age of Criminal Responsibility.

(177.) Commentary to Beijing Rules 4.1.

(178.) CRC Committee, “General Comment No. 10,” 32.

(179.) CRC Committee, “General Comment No. 10,” para. 32.

(180.) Youth Justice Board, “Cross-National comparison of Youth Justice” (2008), https:// dera.ioe.ac.uk/7996/1/Cross_national_final.pdf (accessed Aug. 20, 2019). See also Maria Lourijsen and Ton Liefaard, "Raising the Minimum Age of Criminal Responsibility," Leiden Law Blog (Mar. 21, 2018), https://leidenlawblog.nl/articles/outline-on-raising-the-minimum-age-of-criminal-responsibility.

(181.) Child Rights International Network (CRIN), “Juvenile Justice: Stop Making Children Criminals," CRIN Policy Paper (Jan. 29, 2013), https://archive.crin.org/en/library/publications/juvenile-justice-stop-making-children-criminals.html. See also Jacqui Gallinetti, "Getting to Know the Child Justice Act," Child Justice Alliance/Children's Rights Project, Community Law Centre, University of the Western Cape (2009); Klarise Anne C. Estorninos, "Batang Bata Ka Pa: An Analysis of the Philippine Minimum Age of Criminal Responsibility in Light of International Standards," Ateneo Law Journal 62, no. 1 (2017): 259-273.

(182.) Chris Cunneen, "Arguments for Raising the Minimum Age of Criminal Responsibility," Comparative Youth Penalty Project Research Report, University of New South Wales, Sydney (2017), https://www.cypp.unsw.edu.au/node/146; Frieder Dünkel, "Juvenile Justice Systems in Europe: Current Situation and Reform Developments."

(183.) Liefaard, “Juvenile Justice from a Children's Rights Perspective.”

(184.) See Cipriani, Children's Rights and the Minimum Age of Criminal Responsibility. See also Liefaard, "Juvenile Justice from a Children's Rights Perspective"; CRIN, “Stop Making Children Criminals"; Downes and Morgan, "Waiting for Ingleby"; Inter-American Commission on Human Rights, "Juvenile Justice and Human Rights in The Americas," OEA/Ser.L/V/II (July 13, 2011).

(185.) See also CRC Committee, “General Comment No. 10.”

\section{Ton Liefaard}


Ton Liefaard is Professor of Children's Rights and holds the UNICEF Chair in Children's Rights at Leiden Law School, Leiden University, the Netherlands. He is Leiden Law School's Vice-Dean for Education and the director of the Master of Law's Programme (LL.M.) on Advanced Studies in International Children's Rights at Leiden University. 